\title{
Nephrotic syndrome and rituximab: facts and perspectives
}

\author{
Dieter Haffner • Dagmar-Christiane Fischer
}

Received: 10 March 2009/Revised: 24 April 2009 /Accepted: 4 May 2009/Published online: 4 June 2009

(C) IPNA 2009

\begin{abstract}
Idiopathic nephrotic syndrome is the most frequent glomerular disease that presents during childhood and is mainly due to minimal change nephropathy (MCNS) and focal-segmental glomerulosclerosis (FSGS). Its treatment is still challenging, with up to $50 \%$ of the patients who are initially steroid sensitive (usually MCNS) being frequent relapsers and requiring additional long-term immunosuppression. However, current immunosuppressive regimens are associated with severe toxicity. Only half of the steroid-resistant patients (usually FSGS) achieve longterm remission even with intensive immunosuppression and plasma exchange. Rituximab (RTX), a chimeric monoclonal antibody inhibiting CD20-mediated B-cell proliferation and differentiation, has recently gained attention as a potentially successful therapy for complicated idiopathic nephrotic syndrome in children. A number of case reports and one prospective non-controlled multicenter trial point to the beneficial effects of RTX as a rescue therapy in children with steroid/cyclosporine-dependent or -resistant nephrotic syndrome. However, publication bias often results in positive outcomes being more likely to be reported than negative ones and, in particular, the safety profile of this drug in this group of patients remains unclear. Therefore, controlled randomized studies are required to assess this issue, to develop treatment guidelines, to
\end{abstract}

D. Haffner · D.-C. Fischer

Department of Pediatrics, University Hospital of Rostock, Rostock, Germany

D. Haffner $(\square)$

Department of Pediatrics, University Hospital of Rostock,

Rembrandtstr. 16/17,

18057 Rostock, Germany

e-mail: dieter.haffner@med.uni-rostock.de evaluate the therapeutic and economical efficacy, and to define criteria for the selection of patients.

Keywords Children · Focal segmental glomerulosclerosis . Minimal change nephropathy · Nephrotic syndrome .

Rituximab · Treatment

\section{Introduction}

Idiopathic nephrotic syndrome is the most frequent glomerular disease that presents during childhood. Its main causes are minimal change nephropathy (MCNS) and focalsegmental glomerulosclerosis (FSGS), and its treatment still remains a challenge for the pediatric nephrologist. Minimal change nephropathy usually responds to steroids, and the long-term prognosis is generally good, whereas FSGS is considered less benign. However, up to $50 \%$ of MCNS patients develop frequently relapsing nephrotic syndrome, requiring additional treatment with immunosuppressive agents, such as cyclophosphamide, cyclosporine (CyA), and mycophenolate mofetil (MMF). Moreover, up to 25\% of frequent relapsers may need prolonged treatment with two or more immunosuppressive drugs, with the result that these patients develop the entity of steroid- or CyAdependent nephrotic syndrome [1], with the associated high risk of further developing severe drug toxicity, including growth failure, gonadotoxicity, hypertension, and renal failure. The release of cytokine by T-cells has long been thought to play a key role in the pathogenesis of MCNS. More recently, however, data have accumulated pointing to a strong contribution of B-cell immunity in children with steroid-sensitive MCNS [2, 3].

Focal-segmental glomerulosclerosis is characterized by an even worse prognosis than MCNS. Patients usually 
present with steroid-resistant nephrotic syndrome. Even with intensive immunosuppressive protocols, including glucocorticoid pulses, CyA, cyclophosphamide, and additional plasma exchanges, remission of the nephrotic syndrome is achieved in a maximum of $50-70 \%$ of patients $[4,5]$. Failure to active remission of the nephrotic syndrome ultimately results - over the long term - in end-stage renal disease. Moreover, relapse of the FSGS after renal transplantation is observed in $14-50 \%$ of all patients [6]. In most cases, proteinuria occurs within 2 weeks and results in graft loss if remission cannot be achieved. This condition is believed to be caused by an as yet not well characterized circulating permeability factor.

According to current concepts, not only T-cells but also B-cells are actively involved in the pathogenesis of idiopathic nephrotic syndrome. In particular, the as yet unidentified circulating permeability factor may be released directly from B-cells (i.e. it is an immunoglobulin) or secondary to an aberrant cross-talk between T- and B-cells. These hypotheses are supported by (1) the recurrence of nephrotic syndrome after renal transplantation, (2) the reduction in the total B-cell count during remission of nephrotic syndrome, and (3) remission of the disease by depletion of B-cells [7-10]. The latter can be achieved through administration of the chimeric monoclonal antibody rituximab (RTX), which inhibits CD20-mediated Bcell proliferation and differentiation. The CD20 antigen is a membranous protein found on B-cells as well as on malignant cells, such as non-Hodgkin's lymphoma (NHL). It was first introduced for the treatment of B-cell NHL and subsequently administered to patients with autoimmune diseases, such as rheumatoid arthritis, lupus erythematodes, or immunocomplex glomerulonephritis [11-13].

During the last 5 years, a number of case reports and one prospective multicenter trial have been published on the use of RTX in children with complicated idiopathic nephrotic syndrome. The objective of this article is to critically analyze the results obtained in these preliminary studies and to propose future perspectives for this drug in cases of complicated idiopathic nephrotic syndrome. Children showing MCNS at the time of renal biopsy may subsequently present with either steroid-sensitive, steroid- or CyAdependent, or even with steroid-resistant nephrotic syndrome. Therefore, we have used the clinical response to these drugs rather than renal histology to categorize the disease entities in our analysis.

\section{Method}

We searched Pubmed with the combination of the key words, 'rituximab', 'nephrotic syndrome', and 'children'. Patients with lupus nephritis were excluded. A systematic review was performed to analyze all articles in terms of the initial clinical presentation of patients and the efficacy and safety of RTX.

\section{Rituximab in children with steroid- or CyA-dependent nephrotic syndrome}

Table 1 provides an overview of the use of RTX in children with steroid- or CyA-dependent nephrotic syndrome. This summary is based on five case reports and 22 patients enrolled in a prospective multicenter trial [9, 14-18]. Patients enrolled in this multicenter trial suffered from frequently relapsing nephrotic syndrome necessitating intensive immunosuppressive therapy, including glucocorticoids, calcineurin inhibitors, cyclophosphamide, levamisol, and MMF, which was either not effective in inducing lasting remission and/or associated with severe drug toxicity [17]. In all except three children renal biopsy showed MCNS, and these patients suffered from FSGS. Rituximab was given as a rescue therapy to spare other immunosuppressive treatments. Most of the patients received from two to four weekly doses of RTX $\left(375 \mathrm{mg} / \mathrm{m}^{2}\right)$, and RTX treatment was generally repeated if peripheral CD19 cell counts increased to more than $1 \%$.

In three of four patients presented in case reports who were free of proteinuria at the onset of RTX treatment, an ongoing remission of the nephrotic syndrome during a follow-up of 4-16 months was noted [9, 14-16]. However, in two of these individually recorded patients, RTX was repeated as the patients showed a relapse of the nephrotic syndrome [15, 18]. The girl reported by Gilbert et al. showed a relapse after 9 months, shortly following the reappearance of her CD19 cells. She responded to a second course of RTX [15]. One other patient who was nephrotic at the start of RTX treatment partly responded (decrease in proteinuria from 10 to $1 \mathrm{~g}$ /day within 4 months) [18]; in addition, prednisolone, tacrolimus, and MMF could be tapered and discontinued in this patient. The return of CD19 cells was observed after 9 months, and a relapse occurred at 13 months. Low-dose prednisolone was not effective. Although, a second course of RTX resulted in complete B-cell depletion, no remission of proteinuria could be achieved [18].

In the French multicenter trial, RTX was started during a proteinuria-free period in 15 of 22 patients; the remaining patients were nephrotic [17]. One of the latter patients showed FSGS. The median disease duration before RTX was 11 years (3.6-16.5). The administration of RTX resulted in a complete depletion of peripheral B-cells (i.e. CD19 count $=0$ ) in all patients that lasted from 2 to 11 months (median 6 months). The efficacy of RTX treatment strongly depended on the state of proteinuria at the start of RTX treatment. Seven patients were nephrotic at 
Table 1 Rituximab in children with steroid- or cyclosporine-dependent nephrotic syndrome

\begin{tabular}{|c|c|c|c|c|c|c|c|c|}
\hline Study & $n$ & Histology & $\begin{array}{l}\text { Age at start } \\
\text { of RTX } \\
\text { (years) }\end{array}$ & Immunosuppression & RTX dose & Response & $\begin{array}{l}\text { Follow-up } \\
\text { (months) }\end{array}$ & Relapse \\
\hline $\begin{array}{l}\text { Benz et al. } \\
2004[14]\end{array}$ & 1 & FSGS & 15 & $\begin{array}{l}\text { Pred, CyA, } \\
\text { Tac, CP }\end{array}$ & $\begin{array}{l}375 \mathrm{mg} / \mathrm{m}^{2} \\
\text { weekly } 4 \times\end{array}$ & $\mathrm{CR}^{\mathrm{a}}$ & 12 & No \\
\hline $\begin{array}{l}\text { Gilbert et al. } \\
2006 \text { [15] }\end{array}$ & 1 & MCNS & 15 & $\begin{array}{l}\text { Pred, Tac, CyA, } \\
\text { levamisol, CP }\end{array}$ & $\begin{array}{l}375 \mathrm{mg} / \mathrm{m}^{2} \\
\text { weekly } 4 \times\end{array}$ & $\mathrm{CR}^{\mathrm{a}}$ & 16 & $\begin{array}{l}\text { After } 9 \text { months } \\
\text { responding to RTX }\end{array}$ \\
\hline $\begin{array}{l}\text { Hofstra et al. } \\
2007 \text { [16] }\end{array}$ & 1 & MCNS & 13 & $\begin{array}{l}\text { Pred, CyA, } \\
\text { MMF, CP }\end{array}$ & $\begin{array}{l}1 \mathrm{~g} \text { every other } \\
\text { week } 2 \times\end{array}$ & $\mathrm{CR}^{\mathrm{a}}$ & 4 & No \\
\hline $\begin{array}{l}\text { Smith et al. } \\
2007 \text { [9] }\end{array}$ & 1 & MCNS & 13 & $\begin{array}{l}\text { Pred, Tac, } \\
\text { MMF }\end{array}$ & $375 \mathrm{mg} / \mathrm{m}^{2} 1 \times$ & $\mathrm{CR}^{\mathrm{a}}$ & 6 & No \\
\hline $\begin{array}{l}\text { Peters et al. } \\
2008 \text { [18] }\end{array}$ & 1 & MCNS & 20 & Pred, MMF, Tac & $\begin{array}{l}1 \mathrm{~g} \text { every other } \\
\text { week } 2 \times\end{array}$ & $\mathrm{PR}^{\mathrm{b}}$ & 16 & $\begin{array}{l}\text { After } 13 \text { months } \\
\text { resistant to RTX }\end{array}$ \\
\hline $\begin{array}{l}\text { Guignois et al. } \\
2008 \text { [17] }\end{array}$ & 22 & $\begin{array}{l}\text { MCNS } 16, \\
\text { FSGS } 3\end{array}$ & $\begin{array}{c}14.3 \text { (range: } \\
6.3-22.1 \text { ) }\end{array}$ & $\begin{array}{l}\text { Pred, CyA, Tac, } \\
\text { MMF, CP }\end{array}$ & $\begin{array}{l}375 \mathrm{mg} / \mathrm{m}^{2} \text { weekly } \\
2-4 \times ; \text { additional } \\
\text { courses if CD19 } \\
\text { count }<1 \%\end{array}$ & $\begin{array}{l}\text { CR } 15 / \\
15^{\mathrm{a}} \\
\text { CR } 3 / 7^{\mathrm{b}}\end{array}$ & $\begin{array}{l}9.5 \text { (range: } \\
6-39 \text { ) }\end{array}$ & $\begin{array}{l}\text { In } 3 / 15 \text { after } \\
7-13 \text { months } \\
\text { responding to RTX }\end{array}$ \\
\hline
\end{tabular}

RTX, Rituximab; MCNS, minimal change nephropathy; FSGS, focal-segmental glomerulosclerosis; PR, partly remission; CR, complete remission; Pred, prednisolone; CyA, cyclosporine; MMF, mycophenolate mofetil; MP, methylprednisolone; Aza, azathioprine; CP, cyclophsophamide; Dexa, dexamethasone

${ }^{\text {a }}$ Patients were free of proteinuria at time of RTX treatment initiation

${ }^{\mathrm{b}}$ Patients were nephrotic at time of RTX treatment initiation

the time of RTX initiation, despite previous multiple immunosuppressive regimens. Of note, the addition of RTX to the otherwise unchanged immunosuppressive regimen induced remission in three of these patients after 21,69 , and 81 days, respectively.

In patients free of proteinuria at the start of RTX treatment, the concomitant immunosuppressive regimen could be significantly reduced (mean dose reduction 70\%) after RTX administration with no relapse of proteinuria and without increasing other immunosuppressive drugs. One or more immunosuppressive treatments could be withdrawn in $19 / 22$ patients (85\%), and complete withdrawal was achieved in $5 / 22$ patients (23\%). Thus, RTX was effective in all patients when administered during a proteinuria-free period in association with other immunosuppressive agents.

When relapses did occur, they were usually associated with an increase in CD19 cell count; however, nine patients did not relapse despite the reappearance of CD19 cells at similar levels. Overall, adverse effects were observed in about half of the reported patients [17]. These were mild in five patients (cutaneous eruption, abdominal pain, headache, or mild hypotension) [17]. One patient showed atrial arrhythmia at the end of the first infusion, which did not reappear during subsequent infusions. One patient each showed transient bronchospasm or neutropenia with gingivitis. The latter patient subsequently developed Pneumocystis carinii pneumonia (PCP) despite cotrimoxazole prophylaxis during combined treatment with prednisolone, tacrolimus, and RTX. Therefore, the efficacy of PCP prophylaxis in patients on RTX treatment has to be clarified. In addition, hypogammaglobulinemia was observed in about half of the patients, and prolonged hypogammaglobulinemia has been reported. Thus, close monitoring for hypogammaglobulinemia is mandatory, and guidelines for immunoglobulin substitution in these patients have to be established. Despite these limitations, preliminary results on RTX as a rescue therapy in children with complicated steroid- or CyA-dependent nephrotic syndrome are promising to date.

\section{Rituximab in children with steroid-resistant nephrotic syndrome}

Ten children treated with RTX for steroid-resistant nephrotic syndrome have been reported to date (Table 2) [18-21]. Renal biopsy showed FSGS in eight of these children and MCNS in two. The patients presented with persistent nephrotic syndrome despite intensive immunosuppressive treatment including oral/intravenous (i.v.) glucocorticoids, calcineurin inhibitors, MMF, and cyclophosphamide. In addition, previous plasma exchanges performed in two patients were ineffective. Rituximab was given in one up to four weekly doses of $375 \mathrm{mg} / \mathrm{m}^{2}$ in all except one patient who twice received doses of $1 \mathrm{~g}$ every second week. Treatment with RTX resulted in complete remission in eight of the ten children within 8 months. However, one has to keep in mind that all patients remained on concomitant treatment with prednisolone and/or calcineurin inhibitors during the observation period. Each of these patients 
Table 2 Rituximab in children with steroid-resistant nephrotic syndrome

\begin{tabular}{|c|c|c|c|c|c|c|c|c|}
\hline Study & $n$ & Histology & $\begin{array}{l}\text { Age at start } \\
\text { of RTX (years) }\end{array}$ & $\begin{array}{l}\text { Immunosuppression/ } \\
\text { plasma exchange }\end{array}$ & RTX dose & Response & $\begin{array}{l}\text { Follow-up } \\
\text { (months) }\end{array}$ & Relapse \\
\hline $\begin{array}{c}\text { Bagga et al. } \\
2007 \text { [19] }\end{array}$ & 5 & $\begin{array}{l}\text { FSGS 3, } \\
\text { MCNS } 2\end{array}$ & $2.8-16$ & $\begin{array}{l}\text { i.v. MP, CP, CyA, } \\
\text { MMF, Aza, Tac }\end{array}$ & $\begin{array}{l}375 \mathrm{mg} / \mathrm{m}^{2} \\
\text { weekly } 4 \times\end{array}$ & $\begin{array}{l}\text { CR } 4 \\
\text { PR } 1\end{array}$ & $3.5-14.5$ & $\begin{array}{l}\text { One PR after Pred } \\
\text { No }\end{array}$ \\
\hline $\begin{array}{l}\text { Nakayama } \\
\text { et al. } 2008 \text { [20] }\end{array}$ & 2 & FSGS & 10,12 & i.v. MP, PE & $375 \mathrm{mg} / \mathrm{m}^{2} 1 \times$ & CR 2 & 8,15 & $\begin{array}{l}1 \mathrm{CR} \text { after } \\
\text { 2nd RTX }\end{array}$ \\
\hline $\begin{array}{l}\text { Peters et al. } \\
2008 \text { [18] }\end{array}$ & 2 & FSGS & 15,20 & Pred, MMF & $\begin{array}{l}1 \mathrm{~g} \text { every other } \\
\text { week } 2 \times\end{array}$ & CR 1 , none 1 & 7,10 & No \\
\hline $\begin{array}{l}\text { Suri et al. } 2008 \\
\text { [21] }\end{array}$ & 1 & FSGS & 0.9 & $\begin{array}{l}\text { Pred, CyA, MMF, } \\
\text { Dexa, PE }\end{array}$ & $\begin{array}{l}375 \mathrm{mg} / \mathrm{m}^{2} \\
\text { weekly } 4 \times\end{array}$ & CR 1 & 3 & No \\
\hline
\end{tabular}

PE, Plasma exchange, i.v., intravenous

showed partial or no remission after RTX [18, 19]. The patient showing no remission to RTX presented with $80 \%$ sclerosed glomeruli, suggesting irreversible damage before treatment with RTX [18]. On the other hand, successful treatment with RTX of a patient with FSGS and a diminished renal function has been described [20]. A relapse of the nephrotic syndrome occurred in two of eight patients initially responding to RTX; this was completely resolved after a second course of RTX or prednisolone treatment. No side effects of RTX were reported in these small patient cohorts. Although the reported overall positive responses are rather promising, one must be aware of publication bias, since positive outcomes are more likely to be reported than negative ones.

\section{Rituximab in children with recurrent FSGS after renal transplantation}

To date, five pediatric patients with recurrent FSGS after transplantation who received RTX have been described
[22-25] (Table 3). None of these patients responded to high dosages of calcineurin inhibitors, and they also responded only partly to plasma exchanges, which were performed in four of five patients. In the majority of patients, RTX was given in weekly doses of $375 \mathrm{mg} / \mathrm{m}^{2}$ for 2-6 weeks, whereas one patient twice received $750 \mathrm{mg} / \mathrm{m}^{2}$ every second week.

Overall response was variable and less effective than that in patients with steroid-dependent nephrotic syndrome or steroid-resistant nephrotic syndrome in their native kidneys. Two patients showed complete response within 9 months, one patient showed partly response within 2 months, and two patients were non-responsive to RTX. However, interpretation of these data is more difficult. In two patients showing complete remission after RTX, RTX was originally given to treat coexisting post-transplant lymphoproliferative disease (PTLD) [24, 25]. It cannot be excluded that the development of FSGS in these patients was related to PTLD. In the other patients, RTX was given in combination with plasma exchanges, making it impossible to draw conclusions on the efficacy of RTX contribution. On the

Table 3 Rituximab in children with recurrent FSGS after transplantation

\begin{tabular}{|c|c|c|c|c|c|c|c|c|}
\hline Study & $n$ & $\begin{array}{l}\text { Age at start } \\
\text { of RTX } \\
\text { (years) }\end{array}$ & Immunosuppression & $\begin{array}{l}\text { Previous plasma } \\
\text { exchange }\end{array}$ & RTX dose & Response & $\begin{array}{l}\text { Follow-up } \\
\text { (months) }\end{array}$ & Comments \\
\hline $\begin{array}{l}\text { Nozu et al. } 2005 \\
{[24]}\end{array}$ & 1 & 12 & CyA & No & $\begin{array}{l}375 \mathrm{mg} / \mathrm{m}^{2} \text { once } \\
\text { weekly } 4 \times\end{array}$ & $\begin{array}{l}\text { CR within } \\
7 \text { months }\end{array}$ & 36 & $\begin{array}{l}\text { Tx with RTX } \\
\text { because of PTLD }\end{array}$ \\
\hline $\begin{array}{l}\text { Pescovitz et al. } \\
2006[25]\end{array}$ & 1 & 7 & Tac, MMF & Yes, response? & $\begin{array}{l}375 \mathrm{mg} / \mathrm{m}^{2} \text { once } \\
\text { weekly } 6 \times\end{array}$ & $\begin{array}{l}\text { PR within } \\
2 \text { months }\end{array}$ & 16 & $\begin{array}{l}\text { Tx with RTX } \\
\text { because of PTLD }\end{array}$ \\
\hline $\begin{array}{l}\text { Marks and } \\
\text { McGraw } \\
2007[23]\end{array}$ & 2 & 6,10 & Pred, Tac, MMF & $\begin{array}{l}\text { Yes, partial } \\
\text { response }\end{array}$ & $\begin{array}{l}375 \mathrm{mg} / \mathrm{m}^{2} \text { once } \\
\text { weekly } 4 \times ; 750 \mathrm{mg} / \mathrm{m}^{2} \\
\text { every other week } 2 \times\end{array}$ & None & 5,14 & $\begin{array}{l}\text { No complete } \\
\text { B-cell depletion }\end{array}$ \\
\hline $\begin{array}{l}\text { Apeland et al. } \\
2008 \text { [22] }\end{array}$ & 1 & 18 & Pred, Tac, MMF & $\begin{array}{l}\text { Yes, partial } \\
\text { respone }\end{array}$ & $\begin{array}{l}375 \mathrm{mg} / \mathrm{m}^{2} \text { every } \\
\text { other week } 2 \times ; \\
\text { additional courses } \\
\text { after } 10 \text { and } \\
20 \text { months }\end{array}$ & $\begin{array}{r}\text { CR within } \\
9 \text { months }\end{array}$ & 21 & \\
\hline
\end{tabular}

PTLD, Post-transplant lymphoproliferative disease 
other hand, response to RTX may be very slow and can thus be easily overlooked [22]. In two patients nonresponsive to RTX, complete B-cell depletion was not achieved, i.e. CD19 cell counts were 2 and 4\%, respectively [23]. No side effects of RTX were reported.

\section{Conclusions and future perspectives}

Although anti-CD20 antibodies are a promising option for treating children with complicated nephrotic syndrome due to MCNS or FSGS, positive results should be interpreted cautiously, since they may be overestimated due to publication bias. To date, only one prospective nonrandomized, uncontrolled study involving an acceptable number of patients with steroid- or CyA-dependent nephrotic syndrome has been reported [17]. The safety profile of RTX in these children remains unclear: it was associated with hypogammaglobulinemia requiring immunoglobulin substitution in about half of the patients, and one patient developed PCP despite cotrimoxazol prophylaxis. Recent concerns have arisen due to reports of reactivation of JC virus and progressive multifocal leukoencephalopathy (PML) in patients receiving RTX for treatment of lupus nephritis (www.fda.gov/medwatch/safety/2006/safety06. htm\#rituxan). At the present time, it is essentially impossible to estimate the risk of RTX-associated PML in patients with nephrotic syndrome. Consequently, careful clinical monitoring and, if indicated, investigation of spinal fluid are mandatory in these patients.

In addition, controlled randomized studies that include patients with steroid-dependent and steroid-resistant nephrotic syndrome are required to prove the efficacy and safety of RTX, to evaluate the cost effectiveness of RTX treatment, and to determine which children will benefit. Although the limited number of patients is a serious obstacle for an adequately powered study, efforts should be taken to initiate such a trial. Suitable primary endpoints of such a multicenter trial are (1) frequence and duration of remission of proteinuria and (2) change in concomitant immunosuppressive medication. In addition, such a trial would allow the investigation of renal histology (i.e. MCNS and FSGS) as a predictor for the efficacy of RTX therapy.

Although not addressed systematically in the published reports, children being nephrotic at the time of RTX treatment appeared to respond only poorly. One may speculate that in these patients urinary loss of RTX is at least partly the cause of the reduced therapeutic efficacy. This together with the thus far unknown pharmacokinetic properties of RTX in children are further issues to be addressed in clinical trials. Furthermore, a careful genetic assessment of patients at the time of enrolment is of outmost importance to prevent the inclusion of patients suffering from hereditary-and thus therapy-resistantforms of nephrotic syndrome who would bias the results. At the present time, it is important to establish guidelines for the rescue treatment of patients with complicated steroid-/CyA-dependent or -resistant nephrotic syndrome. Some patients may show long-lasting B-cell depletion and remission after one single infusion of RTX, whereas others may require several courses. The measurement of the peripheral CD19 cell count (e.g. cut-off value of $1 \%$ ) seems to be only a crude tool for monitoring - and not a reliable means for making a sound decision on whether or not to proceed with RTX therapy. Patients may show relapses while the CD19 cell counts are either elevated or even undetectable. The establishment of nationwide registries could aid in the search for preliminary answers to some of the above-mentioned questions.

\section{References}

1. Hodson EM, Alexander SI (2008) Evaluation and management of steroid-sensitive nephrotic syndrome. Curr Opin Pediatr 20:145150

2. Grimbert P, Audard V, Remy P, Lang P, Sahali D (2003) Recent approaches to the pathogenesis of minimal-change nephrotic syndrome. Nephrol Dial Transplant 18:245-248

3. Kemper MJ, Meyer-Jark T, Lilova M, Muller-Wiefel DE (2003) Combined T- and B-cell activation in childhood steroid-sensitive nephrotic syndrome. Clin Nephrol 60:242-247

4. Plank C, Kalb V, Hinkes B, Hildebrandt F, Gefeller O, Rascher W (2008) Cyclosporin A is superior to cyclophosphamide in children with steroid-resistant nephrotic syndrome-a randomized controlled multicentre trial by the Arbeitsgemeinschaft fur Pädiatrische Nephrologie. Pediatr Nephrol 23:1483-1493

5. Vécsei AK, Muller T, Schratzberger EC, Kircher K, Regele H, Arbeiter K, Schroth B, Aufricht C (2001) Plasmapheresis-induced remission in otherwise therapy-resistant FSGS. Pediatr Nephrol 16:898-900

6. Cochat P, Fargue S, Mestrallet G, Jungraithmayr T, KochNogueira P, Ranchin B, Zimmerhackl LB (2009) Disease recurrence in paediatric renal transplantation. Pediatr Nephrol. doi:10.1007/s00467-009-1137-6

7. Dantal J, Bigot E, Bogers W, Testa A, Kriaa F, Jacques Y, Hurault de Ligny B, Niaudet P, Charpentier B, Soulillou JP (1994) Effect of plasma protein adsorption on protein excretion in kidneytransplant recipients with recurrent nephrotic syndrome. N Engl J Med 330:7-14

8. Iharada A, Kaneko K, Tsuji S, Hasui M, Kanda S, Nishiyama T (2009) Increased nitric oxide production by T- and B-cells in idiopathic nephrotic syndrome. Pediatr Nephrol 24:1033-1038

9. Smith GC (2007) Is there a role for rituximab in the treatment of idiopathic childhood nephrotic syndrome? Pediatr Nephrol 22:893-898

10. Yap HK, Cheung W, Murugasu B, Sim SK, Seah CC, Jordan SC (1999) Th1 and Th2 cytokine mRNA profiles in childhood nephrotic syndrome: evidence for increased IL-13 mRNA expression in relapse. J Am Soc Nephrol 10:529-537

11. Cohen SB, Emery P, Greenwald MW, Dougados M, Furie RA, Genovese MC, Keystone EC, Loveless JE, Burmester GR, Cravets MW, Hessey EW, Shaw T, Totoritis MC (2006) Rituximab for rheumatoid arthritis refractory to anti-tumor 
necrosis factor therapy: Results of a multicenter, randomized, double-blind, placebo-controlled, phase III trial evaluating primary efficacy and safety at twenty-four weeks. Arthritis Rheum 54:2793-2806

12. Jayne D (2008) Role of rituximab therapy in glomerulonephritis. J Am Soc Nephrol. doi:10.1681/ASN.2008070786

13. Willems M, Haddad E, Niaudet P, Kone-Paut I, Bensman A, Cochat P, Deschenes G, Fakhouri F, Leblanc T, Llanas B, Loirat C, Pillet P, Ranchin B, Salomon R, Ulinski T, Bader-Meunier B (2006) Rituximab therapy for childhood-onset systemic lupus erythematosus. J Pediatr 148:623-627

14. Benz K, Dotsch J, Rascher W, Stachel D (2004) Change of the course of steroid-dependent nephrotic syndrome after rituximab therapy. Pediatr Nephrol 19:794-797

15. Gilbert RD, Hulse E, Rigden S (2006) Rituximab therapy for steroid-dependent minimal change nephrotic syndrome. Pediatr Nephrol 21:1698-1700

16. Hofstra JM, Deegens JK, Wetzels JF (2007) Rituximab: effective treatment for severe steroid-dependent minimal change nephrotic syndrome? Nephrol Dial Transplant 22:2100-2102

17. Guigonis V, Dallocchio A, Baudouin V, Dehennault M, HachonLe Camus C, Afanetti M, Groothoff J, Llanas B, Niaudet P, Nivet H, Raynaud N, Taque S, Ronco P, Bouissou F (2008) Rituximab treatment for severe steroid- or cyclosporine-dependent nephrotic syndrome: a multicentric series of 22 cases. Pediatr Nephrol 23:1269-1279
18. Peters HP, van de Kar NC, Wetzels JF (2008) Rituximab in minimal change nephropathy and focal segmental glomerulosclerosis: report of four cases and review of the literature. Neth J Med 66:408-415

19. Bagga A, Sinha A, Moudgil A (2007) Rituximab in patients with the steroid-resistant nephrotic syndrome. N Engl J Med 356:2751-2752

20. Nakayama M, Kamei K, Nozu K, Matsuoka K, Nakagawa A, Sako M, Iijima K (2008) Rituximab for refractory focal segmental glomerulosclerosis. Pediatr Nephrol 23:481-485

21. Suri M, Tran K, Sharma AP, Filler G, Grimmer J (2008) Remission of steroid-resistant nephrotic syndrome due to focal and segmental glomerulosclerosis using rituximab. Int Urol Nephrol 40:807-810

22. Apeland T, Hartmann A (2008) Rituximab therapy in early recurrent focal segmental sclerosis after renal transplantation. Nephrol Dial Transplant 23:2091-2094

23. Marks SD, McGraw M (2007) Does rituximab treat recurrent focal segmental glomerulosclerosis post-renal transplantation? Pediatr Nephrol 22:158-160

24. Nozu K, Iijima K, Fujisawa M, Nakagawa A, Yoshikawa N, Matsuo M (2005) Rituximab treatment for posttransplant lymphoproliferative disorder (PTLD) induces complete remission of recurrent nephrotic syndrome. Pediatr Nephrol 20:1660-1663

25. Pescovitz MD, Book BK, Sidner RA (2006) Resolution of recurrent focal segmental glomerulosclerosis proteinuria after rituximab treatment. N Engl J Med 354:1961-1963 